\title{
Poro de Tabasco cheese: Chemical composition and microbiological quality during its artisanal manufacturing process
}

\author{
María de los Ángeles De la Rosa-Alcaraz, Ángel M. Ortiz-Estrada, Priscilia Y. Heredia-Castro, \\ Adrián Hernández-Mendoza, ๑ Ricardo Reyes-Díaz, Belinda Vallejo-Cordoba, $\odot$ \\ and Aarón F. González-Córdova* (i) \\ Laboratorio de Química y Biotecnología de Productos Lácteos, Coordinación de Tecnología de Alimentos de Origen Animal (CTAOA), \\ Centro de Investigación en Alimentación y Desarrollo, A.C. (CIAD), Carretera Gustavo Enrique Astiazarán Rosas \#46, La Victoria, Hermosillo, \\ Sonora, 83304, México
}

\section{ABSTRACT}

Poro de Tabasco cheese (PTC) is one of the most popular cheeses in southern Mexico. It has been made by traditional, nonstandardized artisanal techniques dating back more than $50 \mathrm{yr}$. These techniques result in the cheese having a heterogeneous chemical and microbiological composition and, consequently, distinct organoleptic characteristics. Scientific interest in artisanal cheese is growing because it represents a source of bacteria with potential health benefits. However, the quality of raw-milk cheeses often does not comply with official sanitary standards. The objective of the present study was to explore the chemical composition and microbiological quality of PTC and to describe its production process. Based on chemical composition, this cheese can be classified as a hard, full-fat, fresh cheese, with moisture on a fat-free basis and fat in dry matter ranging from 41 to $55 \%$ and from 49 to $57 \%$, respectively. The chemical and microbiological composition of PTC varied among the evaluated dairies due to the lack of standardization in the production process. Microbial populations decreased during production, which may be associated with high acidity and high salt and low moisture contents, the presence of lactic acid bacteria or antimicrobial substances, and the drainage of whey. However, despite the absence of Escherichia coli, Salmonella spp., and Listeria monocytogenes in final cheeses for all dairies, Staphylococcus aureus and its toxins were found in some samples from one dairy. Therefore, heat treatment for milk and good manufacturing practices should be implemented throughout the entire production process to ensure a safe product.

Key words: Poro de Tabasco cheese, chemical composition, production process, microbiological quality

Received July 30, 2019.

Accepted November 20, 2019.

*Corresponding author: aaronglz@ciad.mx

\section{INTRODUCTION}

Artisanal Mexican cheeses have been recognized to play an important role in the socioeconomic development of their regions of origin because of their strong connection to regional culture, territory, history, and lifestyle (Morales et al., 2011). These cheeses can be distinguished by their typical aroma and flavor. However, these characteristics may vary among dairies due to diverse factors, such as environmental conditions, including the macro- and microclimate of the place of production. In addition, the properties of the milk, which is generally raw milk, are also important. Milk properties can be influenced, for example, by the natural microbiota of dairy cattle or the type of feed consumed. Finally, the specific production conditions, including the type of coagulant and even the traditional tools used during manufacture, may influence the properties of cheese (González-Córdova et al., 2016). To date, around 40 different varieties of cheese have been recognized as genuine artisanal Mexican cheeses (Villegas et al., 2014).

Popular artisanal cheeses in Mexico include Cocido de Sonora, Oaxaca, Chihuahua, Crema de Chiapas, Bola de Ocosingo, and Poro de Tabasco cheese (PTC), which are named for their traditional regions of production and consumption. These cheeses are produced from unpasteurized milk and therefore do not comply with Mexican standards for food safety. The Mexican standard NOM-243-SSA1-2010 requires that milk used to produce unripened cheeses be pasteurized to kill pathogenic bacteria (SSA, 2010). However, this practice can affect the typical characteristics of cheeses. For example, pasteurization can decrease the lactic acid bacteria (LAB) that often confer these characteristics. Unfortunately, most genuine artisanal Mexican cheeses are in danger of disappearing due to the lack of standardized production processes and the lack of compliance with safety regulations. Scientific studies are needed to evaluate the microbiological safety 
of artisanal cheeses and provide recommendations for improving production processes that would guarantee the product safety (González-Córdova et al., 2016).

Poro de Tabasco cheese is a traditional Mexican cheese produced by artisanal cheesemakers in the Balancán, Tenosique, Jonuta, and Emiliano Zapata regions of Tabasco, Mexico. The production of PTC dates back over 50 years in this region, and the cheese is widely accepted and enjoyed throughout southern Mexico. Recently, its authenticity was protected and guaranteed through the establishment of a collective trademark, and PTC can now only be produced in the river zone of Tabasco. This cheese is characterized by its intense aroma, acidic-salty flavor, and moist texture. When fresh, it has a layered texture or appearance. It also has characteristic small holes or pores that develop from the accumulation and production of gas by autochthonous microorganisms (Cervantes-Escoto et al., 2008; González-Córdova et al., 2016). The artisanal production of PTC by cheesemakers implies a certain lack of standardization that can result in a heterogeneous chemical and microbiological composition and, accordingly, distinct organoleptic characteristics according to the dairy or the batch.

Scientific interest in artisanal cheeses is growing because they represent natural sources of endogenous bacterial strains with health benefits, as previously demonstrated for several bacterial strains isolated from artisanal Mexican cheeses. These strains were found to produce bacteriocin-like substances (Heredia-Castro et al., 2015), immunomodulatory (Reyes-Díaz et al., 2018) and antihypertensive (Beltrán-Barrientos et al., 2018) peptides, conjugated linoleic acid (Sosa-Castañeda et al., 2015), and $\gamma$-aminobutyric acid (Gonzalez-Gonzalez et al., 2019), among other compounds. In this regard, the microbiological exploration of artisanal cheeses provides an important scientific basis for further studies. Therefore, the objectives of the present study were to explore the chemical composition and microbiological quality of PTC and to describe its artisanal production process. This information may contribute toward achieving wider protection, such as designation-oforigin status, for PTC.

\section{MATERIALS AND METHODS}

\section{Sampling}

Six dairies $(\mathrm{A}-\mathrm{F})$ belonging to a collective trademark constituted by 13 dairies located in 3 municipalities from the river zone of Tabasco in southeastern Mexico $\left(17^{\circ} 48^{\prime} \mathrm{N}\right.$ and $\left.91^{\circ} 32^{\prime} \mathrm{W}\right)$ were sampled. The dairies were located at an approximate altitude of $50 \mathrm{~m}$ above sea level. All dairies were sampled in duplicate on 2 separate occasions; the first sampling was taken in September and the second 8 mo later during May (autumn and spring, respectively). Samples of $250 \mathrm{~g}$ or $250 \mathrm{~mL}$ (solid or liquid, respectively, depending on the type of sample) of raw milk (M), natural whey starter culture (NWSC), curds, and leached whey (LW) were aseptically taken during the production of PTC and collected in 250-mL sterile screw-cap polypropylene containers or 710-mL Whirl-Pak sterile sampling bags (Nasco USA, Fort Atkinson, WI). In addition, samples of the final cheeses were collected $7 \mathrm{~d}$ after the start of the production process. All samples were kept under refrigeration until analysis.

\section{Production Process}

The production processes of the 6 dairies were documented and described in stages. The following manufacturing conditions were recorded: temperature, milk volume, type and quantity of ingredients (salt, starter culture, and rennet), amount of leached whey, and time at which each process was performed.

\section{Chemical Composition}

Total solids were determined by the oven drying method (method 990.19), moisture by the numerical difference of total solids, protein by the micro-Kjeldahl method (method 991.20), total fat by the Babcock method (method 989.04), ash by the gravimetric method (method 945.46), and acidity by the titrimetric method for milk and cheese (methods 947.05 and 920.124, respectively), as recommended by AOAC International (2002). The $\mathrm{pH}$ was recorded using a potentiometer (Hanna Instruments pH 211, Cluj, Romania). The content of salt (total chloride) was determined in the final product by the Volhard method (method 935.43). Each measurement was carried out in duplicate for all samples. Additionally, percentages of moisture on a fatfree basis (MFFB) and fat in dry matter (FDM) were calculated according to the Codex General Standard for Cheese (Codex Standard 283-1978) (FAO, 1978), as follows:

MFFB (\%) $=$ [weight of moisture in the cheese/

(total weight of cheese - weight of fat in the cheese)]

$$
\times 100 \text {; }
$$

FDM $(\%)=[$ weight of fat in the cheese/

(total weight of cheese - weight of moisture in the cheese) $] \times 100$. 


\section{Microbiological Quality}

The microbial analyses were performed at each stage of the production process. The samples were collected following the procedures reported by Torres-Llanez et al. (2006). Ten milliliters or $10 \mathrm{~g}$ of the samples (M, NWSC, curds, LW, or cheese) were homogenized in 90 $\mathrm{mL}$ of a sterile $\mathrm{NaCl}$ solution $(0.9 \%)$. Then, decimal dilutions were prepared with a sterile $\mathrm{NaCl}$ solution and were homogeneously poured on dry medium plates (RIDA COUNT, R-Biopharm, Darmstadt, Germany). The determinations were performed in duplicate in different specific media. Aerobic mesophilic bacteria (AMB), total coliform bacteria (TCB), Staphylococcus aureus, and Escherichia coli were counted after incubation at $35^{\circ} \mathrm{C}$ for 24 to $48 \mathrm{~h}$; molds and yeasts (MY) were counted after incubation at $25^{\circ} \mathrm{C}$ for 2 to $5 \mathrm{~d}$. All these determinations were carried out by following the RIDA COUNT supplier instructions.

The LAB were grown and counted on different media. Lactobacillus spp. were grown on de Man, Rogosa, and Sharpe agar (BD Difco, Sparks, MD) and incubated at $37^{\circ} \mathrm{C}$ for $48 \mathrm{~h}$. Lactococcus spp. and Streptococcus spp. were cultured on M17 agar (BD Difco) enriched at $5 \%(\mathrm{vol} / \mathrm{vol})$ with a sterile solution of lactose (BD Difco) prepared at $10 \%(\mathrm{wt} / \mathrm{vol})$ and incubated at 30 and $42^{\circ} \mathrm{C}$, respectively, for $48 \mathrm{~h}$ (Marino et al., 2003; Dagdemir and Ozdemir, 2008).

Salmonella spp. were presumptively determined by following the specifications of ISO 6579:2002 (ISO, 2002). Twenty-five grams or $25 \mathrm{~mL}$ of each sample was pre-enriched in buffered peptone water (1:9) and incubated at $37^{\circ} \mathrm{C}$ for $18 \mathrm{~h}$. Afterward, $100 \mu \mathrm{L}$ of culture was inoculated in $10 \mathrm{~mL}$ of the selective enrichment medium Rappaport Vassiliadis Salmonella (RVS; BD Difco) and incubated at $42^{\circ} \mathrm{C}$ for $24 \mathrm{~h}$. Finally, $1 \mathrm{~mL}$ of the RVS broth was inoculated on XLD dry medium plates (RIDA COUNT) and incubated at $37^{\circ} \mathrm{C}$ for $24 \mathrm{~h}$.

Listeria monocytogenes was analyzed in the final cheese only, applying a confirmatory test in accordance to the standard NOM-243-SSA1-2010 (SSA, 2010). For this analysis, $25 \mathrm{~g}$ of cheese was homogenized in $225 \mathrm{~mL}$ of Listeria enrichment broth (Oxoid, Lenexa, KS) and incubated at $30^{\circ} \mathrm{C}$ for $48 \mathrm{~h}$. The enriched samples were cultured on plates with lithium chloride-phenylethanolmoxalactam agar (Oxoid) and Oxford agar (Oxoid) and incubated at $30^{\circ} \mathrm{C}$ and $35^{\circ} \mathrm{C}$, respectively, for 48 h. The presence of L. monocytogenes was determined according to its biochemical characteristics.

The detection of staphylococcal enterotoxin was performed for cheese samples using the visual immunoassay kit 3M TECRA Staph Enterotoxin VIA, following the supplier's instructions (3M, St. Paul, MN).

\section{Statistical Analysis}

A 1-way ANOVA for a completely randomized design was used to evaluate the microorganism populations and chemical composition in the NCSS-2007 statistical package (Hintze, 2006). Fisher's least significant difference test was applied when significant differences were found. Differences in chemical composition among dairies were assessed to reveal the state of standardization, and differences in microorganism counts among samples for each dairy were assessed to monitor population changes throughout the cheesemaking process. Significance was assessed at a $95 \%$ level of confidence.

\section{RESULTS AND DISCUSSION}

\section{Production Process}

The artisanal production process of PTC is summarized in the diagram in Figure 1. All of these stages are crucial for shaping the acidity and flavor characteristics of the cheese. Poro de Tabasco cheese was made from raw cow milk, mainly from Zebu-Brown Swiss cattle, which was provided by several local farms. The process began with the reception of the raw milk, which was first filtered through a muslin cheesecloth and held at room temperature $\left(30-32^{\circ} \mathrm{C}\right)$. Afterward, the milk was acidified by adding 2 to $5 \%$ (vol/vol) of NWSC with a pH of 3 to 5 (50-80 $0^{\circ}$ Dornic); in this case, the NWSC was the leached whey recovered from batches of the prior day that were allowed to ferment in plastic containers for $24 \mathrm{~h}$ at room temperature. Following acidification, the milk was immediately curdled by incorporating commercial rennet (CUAMIX, Chr. Hansen de Mexico S. A. de C. V., Mexico D. F., Mexico; $5 \mathrm{~mL}$ per $100 \mathrm{~L}$ of milk, diluted to a 1:6 ratio in water) with continuous shaking for 1 to $2 \mathrm{~min}$. Then, the mixture was left to rest for approximately 1 to $1.5 \mathrm{~h}$ until a firm coagulum formed. The curd was cut into small blocks $\left(2 \mathrm{~cm}^{2}\right)$ and left to rest for 2 to $4 \mathrm{~h}$. Then, the curd was placed in rectangular prism-shaped cedar wood molds $(16 \times 11$ $\times 18 \mathrm{~cm}$ ) with small holes, and after whey was drained for $60 \mathrm{~min}$, the molds were flipped to allow further draining for $24 \mathrm{~h}$ at room temperature. In this step, the draining of the curd is slow, and the whey is pressed out only by the weight of the curd itself.

Following draining, the curds were removed from the molds and the compressed mass was sliced in half. Each half was manually rolled in salt to cover its entire surface with a thin coating of salt. The salted pieces were transferred to smaller cedar wooden molds (16 $\times 11 \times 7.5 \mathrm{~cm}$ ) with small holes and pressed in rustic wooden presses with concrete weights of $5 \mathrm{~kg}$ for $2 \mathrm{~d}$ 

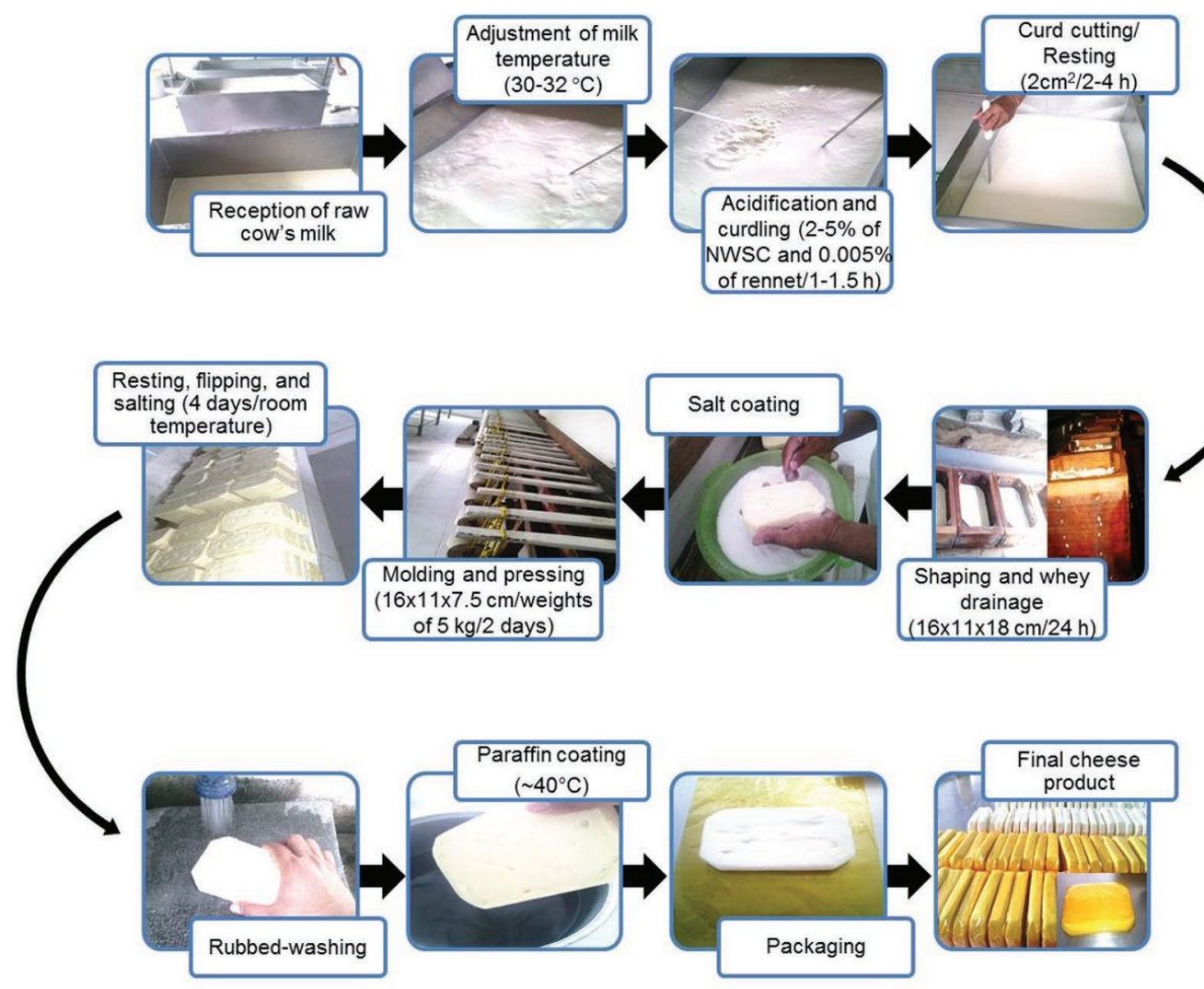

Figure 1. Cheesemaking process of artisanal Poro de Tabasco cheese. NWSC = natural whey starter culture.

at room temperature. Once pressed, the cheeses were left to rest on wooden shelves (commonly called roperos by local cheese makers) for $4 \mathrm{~d}$ at room temperature and were flipped daily. The cheese rinds were salted daily for the first 2 or $3 \mathrm{~d}$ as in the first salting step. Then, the cheeses were rubbed-washed on a concrete slab (or metate, a stone slab) with potable tap water until the rinds formed during the resting period were removed. The cheeses were left to rest again for $4 \mathrm{~h}$ at room temperature before being dipped in food-grade paraffin wax (at $\sim 40^{\circ} \mathrm{C}$ ) for protection from drying and contamination. Finally, when the paraffin wax coating was dried, the cheeses were wrapped in yellow or red cellophane and labeled. At this point, the cheeses were ready to be sold and consumed. According to the Codex Standard 283-1978 (FAO, 1978), this cheese was unripened. However, it may take up to 4 wk for cheeses produced in this manner to be sold.

\section{Chemical Composition}

The chemical composition of PTC is shown in Table 1. Milk is a very complex and variable biological fluid, and its composition varies by animal and breed and depends on the health and nutritional status of the animal, stage of lactation, age, and so forth. The raw milk used by the dairies was normal based on its water, total solids, protein, and fat contents (87-91\%, 9-13\%, $2.9-3.5 \%$, and $2.3-3.8 \%$, respectively), which were within the ranges previously reported for cow milk (Fox and McSweeney, 1998).

However, the acidity of milks varied significantly $(P$ $<0.01)$ among dairies. The milk samples from dairies $\mathrm{A}, \mathrm{E}$, and $\mathrm{F}$ were statistically equal $(P>0.05)$. According to Fox and McSweeney (1998), these milks were nonacidic because their acidity values ranged from 1.4 to $1.6 \mathrm{~g} / \mathrm{L}$. In contrast, the acidity of the milks from dairies B, C, and D surpassed this range, suggesting the beginning of a fermentative process. However, a significant relationship was not found $(\mathrm{r}=-0.30, P=0.55)$ between the $\mathrm{pH}$ value of NWSC and the $\mathrm{pH}$ of the final cheeses. The use of NWSC can lower the pH of milk, but NWSC is later discarded with the leached whey during cheesemaking. Notably, the curd of dairy F had significantly $(P<0.01)$ higher acidity, which may have been due to a longer resting time after the addition of the NWSC or a deficient drainage of whey. The acidifying capacity of the microbial population present during 


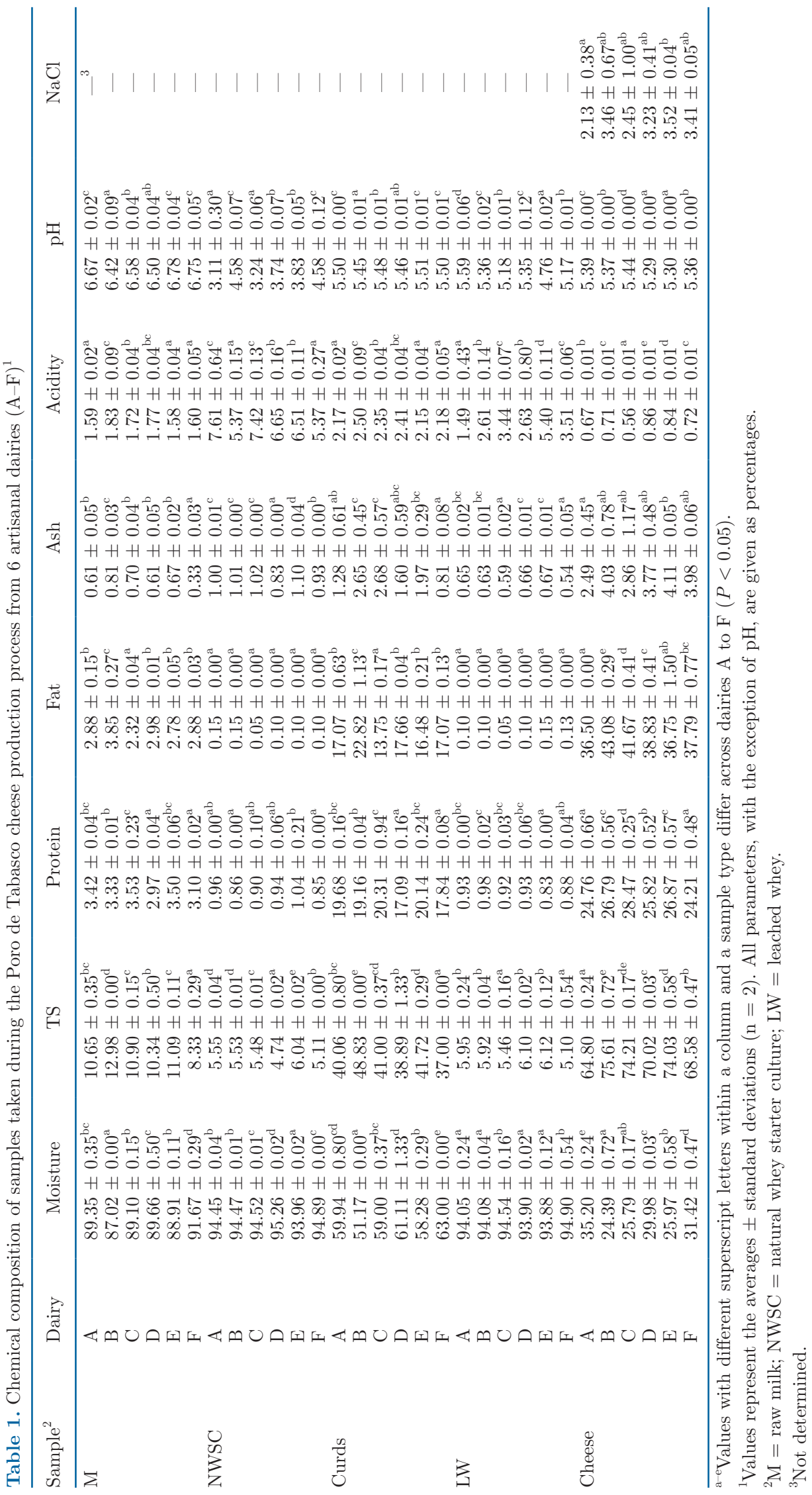


each process might also have contributed to the differences, possibly explaining the high levels of acidity in the cheeses from dairies D and E.

Importantly, none of the sampled cheeses had sufficient acidity ( $\mathrm{pH}$ range of 5.2-5.4) to inhibit pathogenic microorganisms. High-moisture cheeses with a $\mathrm{pH}$ value of 4.6 or lower were previously reported to be safe (Fox et al., 2004). Also, acidity levels may increase after commercialization because up to 4 wk may pass before cheeses are purchased and consumed (González-Córdova et al., 2016). During this time, the $\mathrm{pH}$ decreases, although it may not be sufficient to fully inhibit the growth of pathogenic microorganisms in high-moisture cheeses. For this reason, public health authorities in many countries recommend a minimum ripening time of $60 \mathrm{~d}$ (Fox et al., 2004).

Significant differences $(P<0.05)$ were also found in the moisture, protein, fat, and ash contents of curds and cheeses. These results reflect the lack of standardization in the production of PTC, especially in regard to whey draining and curd pressing, because the raw materials showed low variability. A wide range of values were observed for the moisture (and thus total solids), protein, fat, ash, and $\mathrm{NaCl}$ contents of the final cheeses (24-35\%, 24-28\%, 36-43\%, 2.4-4.1\%, and $2.1-3.5 \%$, respectively). To obtain a standardized product, it is imperative that cheesemakers use standardized processes. According to the Codex Standard 283-1978 (FAO, 1978), cheeses may be classified in terms of MFFB and FDM. In this case, the cheeses showed a wide variation in MFFB and FDM, with ranges of 41 to $55 \%$ and 49 to $57 \%$ (data not shown), respectively. With corresponding averages of 47 and $55 \%$, respectively, PTC could be classified as an extra-hard and full-fat cheese.

\section{Microbiological Quality}

The sensory qualities of cheese depend on multiple factors, including the chemical composition, but mainly the microbiota (Alegría et al., 2009). Therefore, hygienic practices are crucial during each stage of cheese manufacture and storage to ensure the safety of the final product.

The results for the microbiological quality of the PTC samples are shown in Figures 2 and 3. All the cheese manufacturers started with raw milk with a high microorganism count, ranging from 6 to $8 \log _{10} \mathrm{cfu} / \mathrm{mL}$ for Lactococcus spp., 6 to $9 \log _{10} \mathrm{cfu} / \mathrm{mL}$ for Streptococcus spp., 7 to $8 \log _{10} \mathrm{cfu} / \mathrm{mL}$ for Lactobacillus spp., 7 to $9 \log _{10} \mathrm{cfu} / \mathrm{mL}$ for $\mathrm{AMB}, 5$ to $8 \log _{10} \mathrm{cfu} / \mathrm{mL}$ for TCB, and 5 to $6 \log _{10} \mathrm{cfu} / \mathrm{mL}$ for MY. According to Mexican official standard NOM-243-SSA1-2010 (SSA, 2010), the milk used as raw material for manufacturing dairy products must be subjected to a heat treatment to guarantee the safety of the final product, and the microbiological parameters of the milk must also fall within standard permissible limits. Also, obtaining a negative phosphatase test is important to ensure that milk has been adequately pasteurized. However, in the present study, the NWSC showed a high microorganism count, surpassing the limits established for milk. In particular, according to Mexican standard NOM091-SSA1-1994 (SSA, 1994), the permissible limits for AMB and TCB in pasteurized milk are 4.4 and $1.3 \log _{10}$ $\mathrm{cfu} / \mathrm{mL}$, respectively, whereas limits for $\mathrm{MY}$ are not established. Despite the poor quality of the raw materials used in the present study, all counts for Lactococcus spp., Streptococcus spp., Lactobacillus spp., AMB, and TCB decreased significantly $(P<0.05)$ by the end of the cheesemaking process in all sampled dairies.

In addition, LAB might be present in milk due to contamination and the lack of good manufacturing practices, yet these bacteria are widely recognized and considered to be safe microorganisms. Neither national nor international standards (FAO, 1978; SSA, 2010) establish permissible limits for LAB in cheese, milk, or dairy products. In fact, LAB are widely known to confer some of the typical characteristics of dairy products, such as flavor, aroma, and texture, and they also extend the shelf life of these products; therefore, the presence of these bacteria in cheese can actually be desirable. Our results indicated that LAB decreased during PTC production after curd pressing, which may be due to their elimination during whey draining. In the future, one possibility for retaining the typical characteristics of PTC when using pasteurized milk may be the use of a LAB starter culture specifically designed for this type of cheese.

Regarding additional indicator microorganisms, the permissible limits for AMB are not established by Mexican standards for unripened cheeses. However, these microorganisms are useful indicators of the shelf life and spoilage of foods. Additionally, they are used to evaluate the sanitary quality of foods given that the presence of AMB implies contamination by pathogens (Park and Kim, 2013). Meanwhile, the TCB count of cheese was 2.5 to $3.9 \log _{10} \mathrm{cfu} / \mathrm{g}$. Cheeses from all dairies surpassed the permissible limits $\left(2 \log _{10} \mathrm{cfu} / \mathrm{g}\right)$, except for dairy E, for which TCB were not detected. Similar to AMB, these microorganisms are considered to be indicators of poor sanitation and also imply the presence of E. coli, which must be subsequently confirmed.

In contrast, MY showed less variation throughout the process. Mexican standard NOM-243-SSA1-2010 (SSA, 2010) does not establish permissible limits for MY in raw or pasteurized milk, and few studies have reported on the incidence of these microorganisms. Molds and yeasts are sometimes used as a starter culture, but they 

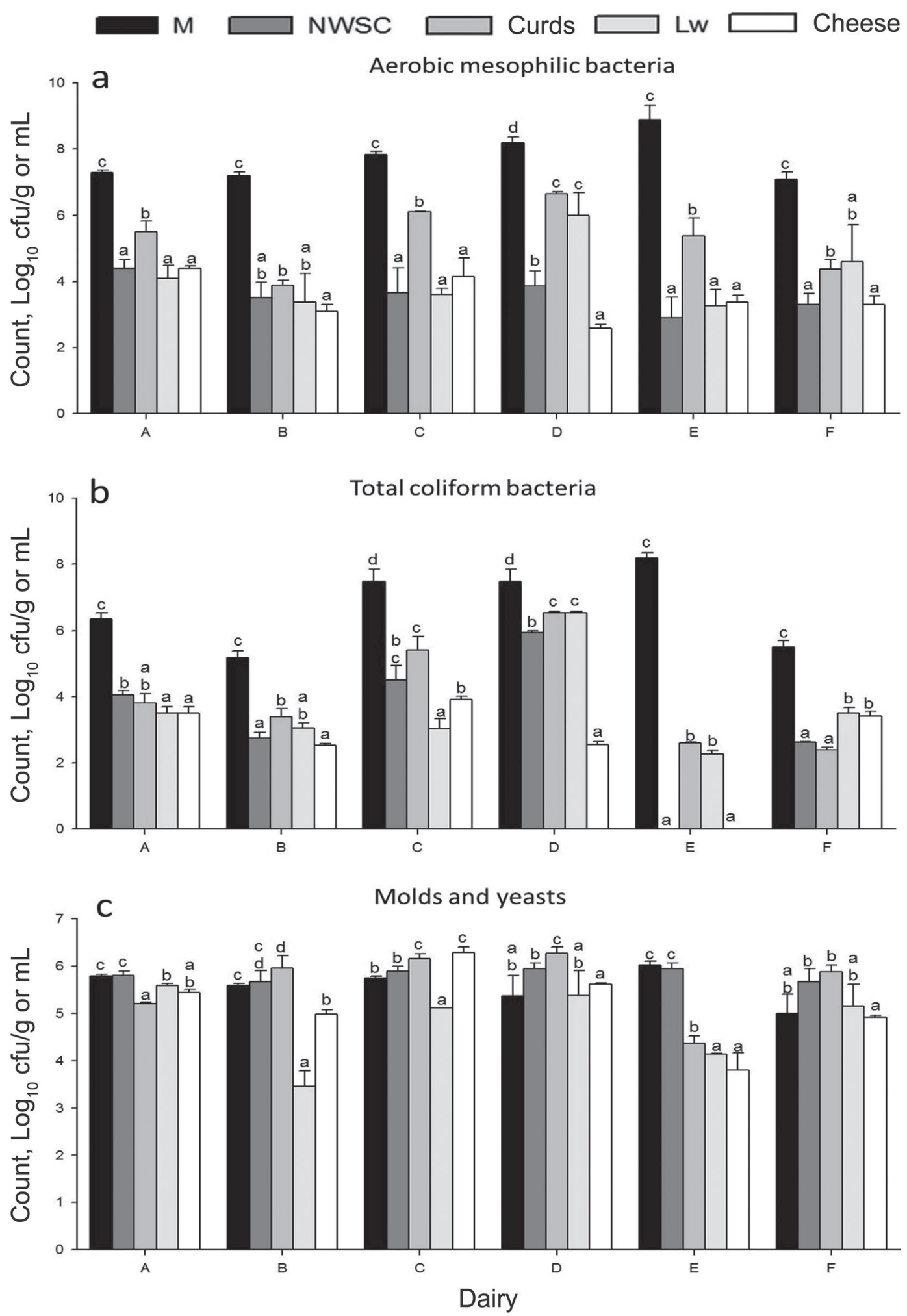

Figure 2. Indicator microorganism counts in samples taken during the Poro de Tabasco production process from 6 artisanal dairies (A-F). Values represent the means \pm standard errors $(\mathrm{n}=2)$. For each group of bacteria, different letters $(\mathrm{a}-\mathrm{d})$ for the same dairy represent significant differences $(P<0.05)$ among sample of raw milk $(\mathrm{M})$, natural whey starter culture (NWSC), curds, leached whey (LW), and cheese. 

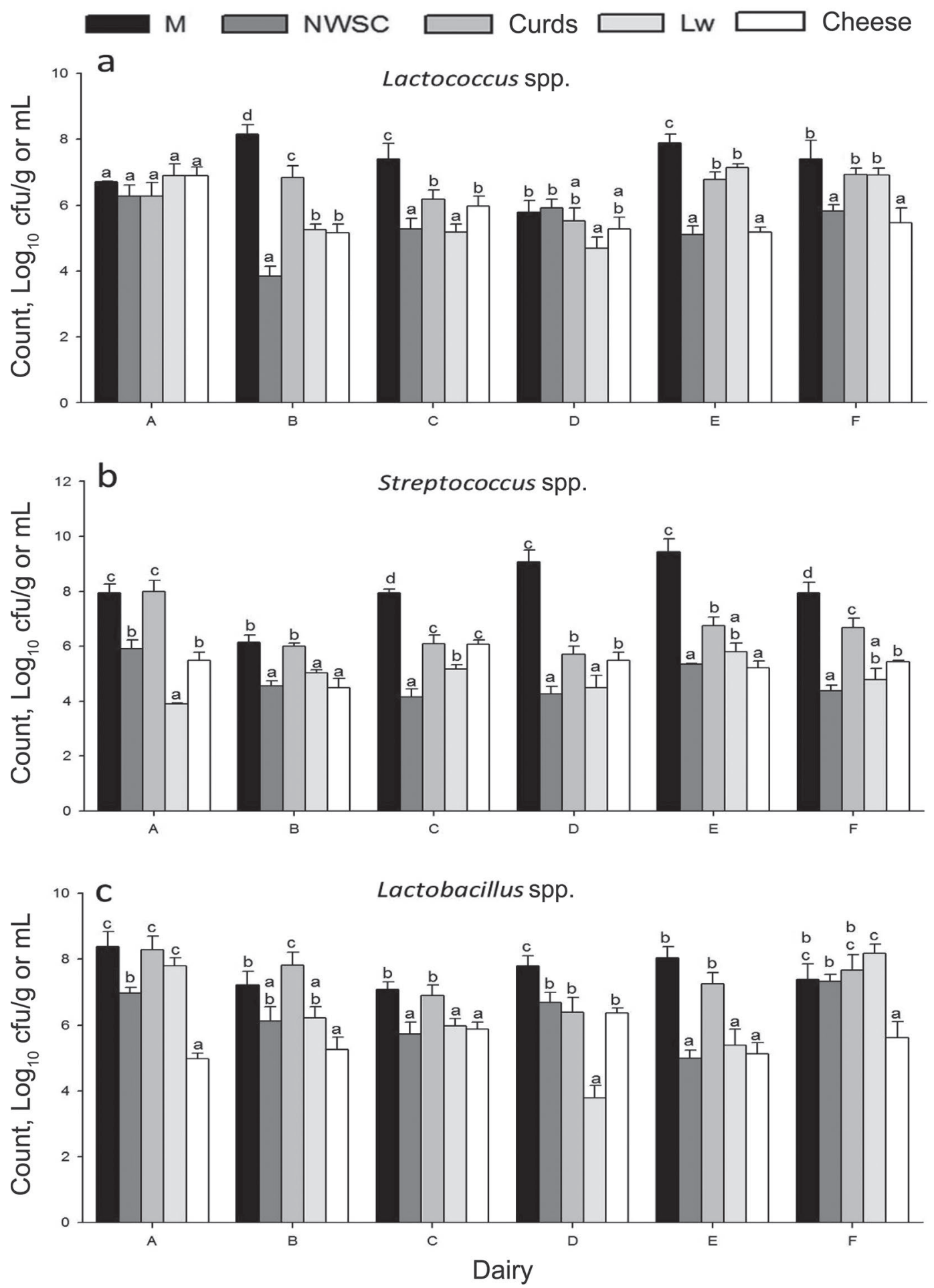

Figure 3. Lactic acid bacterial (LAB) counts in samples taken during the Poro de Tabasco production process from 6 artisanal dairies (A-F). Values represent means \pm standard errors $(\mathrm{n}=2)$. For each LAB genus, different letters $(\mathrm{a}-\mathrm{d})$ for the same dairy represent significant differences $(P<0.05)$ among samples of raw milk $(\mathrm{M})$, natural whey starter culture (NWSC), curds, leached whey (LW), and cheese.

may also enter cheese from different sources, such as ambient air, brine, processing equipment, and workers. Different yeasts can contribute to the taste, flavor, and appearance of cheeses, although some species can cause spoilage. Yeasts are rarely associated with foodborne infections, yet one study showed the presence of 
medically relevant species of Candida in several cheeses, including C. albicans, C. tropicalis, C. krusei, and C. glabrata (Banjara et al., 2015). Populations of fewer than $10^{3} \mathrm{cfu} / \mathrm{mL}$ have mostly been reported in milk, but counts as high as $10^{4} \mathrm{cfu} / \mathrm{mL}$ can occasionally occur (Cocolin et al., 2002). Meanwhile, yeast populations below $3.8 \log _{10} \mathrm{cfu} / \mathrm{mL}$ have been reported in NWSC (Borelli et al., 2006).

Similar to yeasts, molds are often added to certain varieties of cheese to provide desirable characteristics and extend shelf life. However, adventitious molds that contaminate cheese can produce mycotoxins that present a potential health risk (Banjara et al., 2015). Our results found more than $5 \log _{10} \mathrm{cfu} / \mathrm{mL}$ in raw milk and NWSC at all sampled dairies; these populations significantly $(P<0.01)$ decreased during production only at dairies B and E. Notably, all mold counts in cheese (3.8-6.5 $\left.\log _{10} \mathrm{cfu} / \mathrm{g}\right)$ surpassed the permissible limits (2.6 $\left.\log _{10} \mathrm{cfu} / \mathrm{g} ; \mathrm{SSA}, 2010\right)$. Therefore, critical needs include evaluating the production line to determine points of MY contamination and setting up procedures to prevent it.

Regardless of the cheesemaking procedures, indicator microorganisms (AMB, TCB, and MY) tend to be present in high numbers in artisanal Mexican cheeses made from raw milk (Renye et al., 2008; Flores-Magallón et al., 2011; Chombo-Morales et al., 2016; CuevasGonzález et al., 2017), often surpassing the permissible limits, especially in fresh cheeses with a high moisture content, such as Fresco cheese. To lower their numbers, it is important to use pasteurized milk. In some cases, indicator microorganisms can also be reduced when the curds are cooked or ripened, such as in Cocido or Cotija cheeses. Good manufacturing processes can ensure that microorganism counts remain within the established limits. Several additional factors, such as inadequate hygiene during milk production, lack of temperature control during milk transport, and high environmental temperature may affect the quality of the milk and, therefore, the final product. For PTC, neither heat treatments nor a ripening period are phases in its production. The observed reduction in microbial populations during production may be due to their elimination during the drainage of whey or the presence of antimicrobial substances, such as lactic acid, hydrogen peroxide, bacteriocins, and other by-products produced by LAB (Schnürer and Magnusson, 2005; Delbes-Paus et al., 2010).

The presence of specific pathogenic bacteria, such as E. coli, S. aureus (Figure 4), and Salmonella spp. (Table 2) was also analyzed throughout the cheesemaking process. Staphylococcal enterotoxin and $L$. monocytogenes were only found in the final cheese. Escherichia coli had a high initial count (3-6 $\log _{10}$ most probable number/
$\mathrm{mL}$ ) in the raw milk used by dairies, surpassing the permissible limit $\left(0.4 \log _{10}\right.$ most probable number $/ \mathrm{mL}$; SSA, 2010) for milk used to manufacture cheese. Nevertheless, these bacteria were absent in the final cheeses, thereby complying with Mexican standards $\left(<2 \log _{10}\right.$ $\mathrm{cfu} / \mathrm{mL}$ ). The presence of $E$. coli should not be dismissed given that some populations cause intestinal or extraintestinal diseases, mainly Shiga toxin-producing E. coli. Infections with Shiga toxin-producing E. coli represent a public health issue and are considered to be the most important emerging infectious pathogens transmitted by foods of animal origin, such as partially cooked ground beef, unpasteurized milk, and dairy products, as well as dry or fermented meat products, such as salami (Barbosa-Canovas et al., 2004).

Staphylococcus aureus was found in raw milk at a concentration of 4 to $6 \log _{10} \mathrm{cfu} / \mathrm{mL}$, surpassing the permissible limit (absent). This count decreased significantly $(P<0.05)$ by 2 to $3 \log _{10} \mathrm{cfu} / \mathrm{mL}$ in the cheeses produced by dairies B, C, D, and E; however, only the cheeses from dairies $\mathrm{B}$ and $\mathrm{D}$ did not surpass the permissible limit $\left(\leq 3 \log _{10} \mathrm{cfu} / \mathrm{g}\right)$. Notably, the count significantly $(P<0.01)$ increased by $1 \log _{10} \mathrm{cfu} /$ $\mathrm{mL}$ at dairies $\mathrm{A}$ and $\mathrm{F}$. At dairy $\mathrm{A}$, the count surpassed $5 \log _{10} \mathrm{cfu} / \mathrm{g}$, representing a significant risk due to the potential presence of staphylococcal enterotoxins. Special attention should be placed on the presence of staphylococci in dairy products because these bacteria are strongly associated with food poisoning outbreaks worldwide. Surprisingly, despite the high concentration of $S$. aureus throughout PTC production, staphylococcal enterotoxin was not detected in the final cheese, except that of dairy B (as shown in Table 2), which only tested positive in the second sampling. These results highlight that the lack of both heat treatment for milk and good manufacturing processes could potentially increase the intoxication risk for consumers. Toxins could be produced at any stage of the production process, mainly in the milk or NWSC, as well as in the final product. European standards, for example, rely on controlled analyses at the moment when the coagulase-positive staphylococci population is expected to be at its highest: the maximum limits range from $10^{2}$ $\mathrm{cfu} / \mathrm{g}$ of product (in unripened soft cheeses made from milk that has undergone pasteurization or a stronger heat treatment) to $10^{5} \mathrm{cfu} / \mathrm{g}$ (in cheeses made from raw milk) (Delbes-Paus et al., 2010; Cretenet et al., 2011).

Salmonella spp. were detected in the milk and NWSC of all dairies and were therefore also present in the curds and leached whey. Yet, surprisingly, Salmonella spp. were absent in the final cheeses (as seen in Table 2 ), suggesting that the population was lost during whey drainage and curd pressing. These results are important given that Salmonella spp. are highly associated with 
fresh artisanal Mexican cheeses (Moreno-Enriquez et al., 2007; Torres-Vitela et al., 2012) and also responsible for food poisoning (El-Gazzar and Marth, 1992; Colak et al., 2007). Meanwhile, L. monocytogenes was only found in the final cheeses. Despite the usual prevalence of L. monocytogenes in unripened artisanal Mexican cheese (Moreno-Enriquez et al., 2007; Torres-Vitela et al., 2012), this pathogen was absent in all samples taken during the production process. Nevertheless, it is likely to be present in the input milk because of the lack of a heat treatment (EURL, 2014). Special attention should be placed on this pathogen because several outbreaks of foodborne illness presenting a high hospitalization rate $(94 \%)$ have been associated with the consumption of dairy products (Colak et al., 2007), particularly rawmilk cheeses. Certain groups, such as pregnant women, neonates, children, elderly people, and immunocompromised individuals, might be particularly susceptible (Melo et al., 2015). Therefore, although Salmonella spp. and Listeria spp. were absent in cheeses, the risk always exists that these pathogens are in raw milk, similar to E. coli and S. aureus. We recommend that

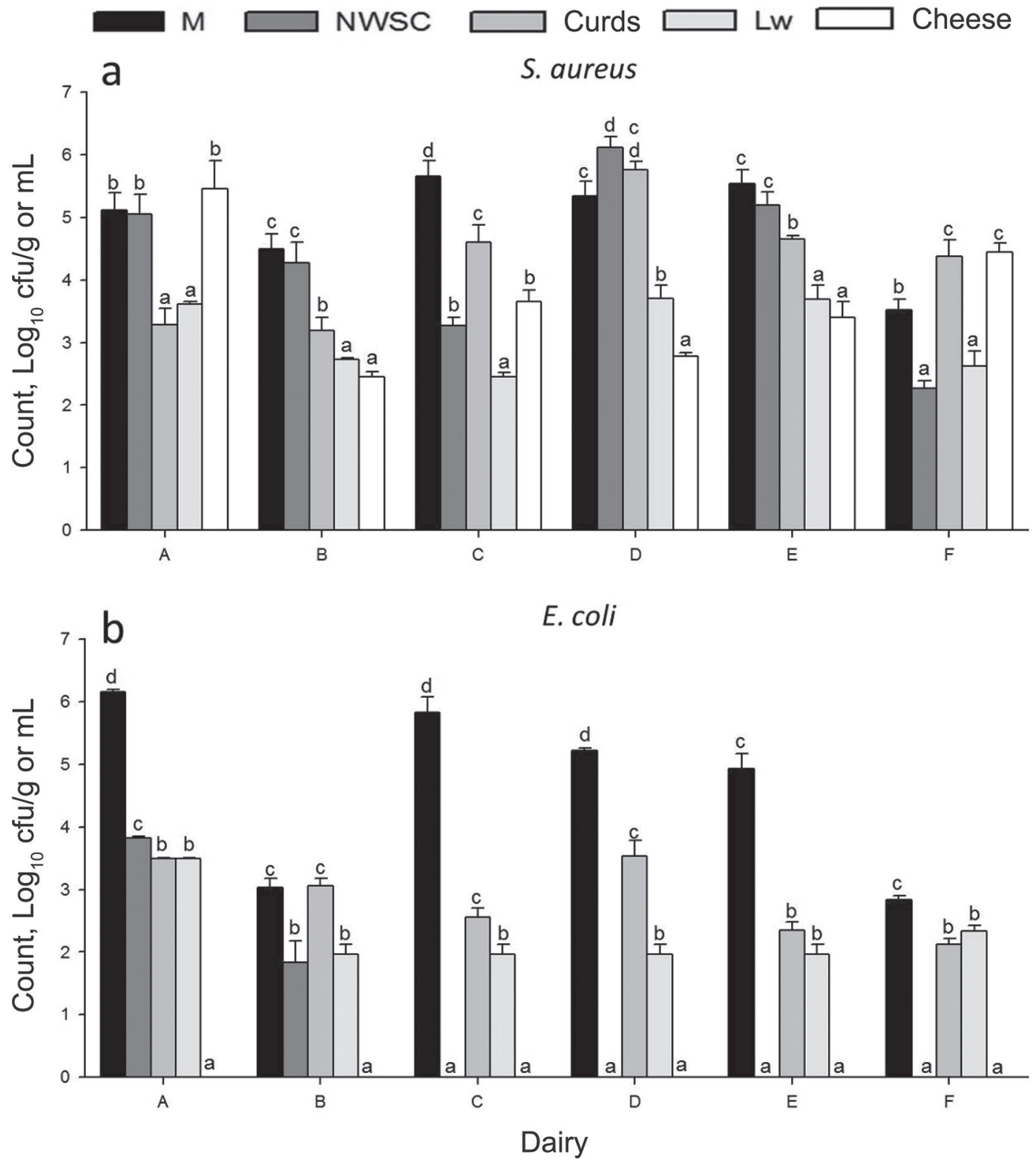

Figure 4. Counts of Staphylococcus aureus and Escherichia coli in samples taken during the Poro de Tabasco production process from 6 artisanal dairies $(\mathrm{A}-\mathrm{F})$. Values represent means \pm standard errors $(\mathrm{n}=2)$. For each pathogenic bacterium, different letters $(\mathrm{a}-\mathrm{d})$ for the same dairy represent significant differences $(P<0.05)$ among samples of raw milk $(\mathrm{M})$, natural whey starter culture (NWSC), curds, leached whey $(\mathrm{LW})$, and cheese. 
Table 2. Presence of Salmonella spp., staphylococcal enterotoxin, and Listeria monocytogenes in samples taken during the Poro de Tabasco cheese production process from 6 artisanal dairies $(\mathrm{A}-\mathrm{F})^{1}$

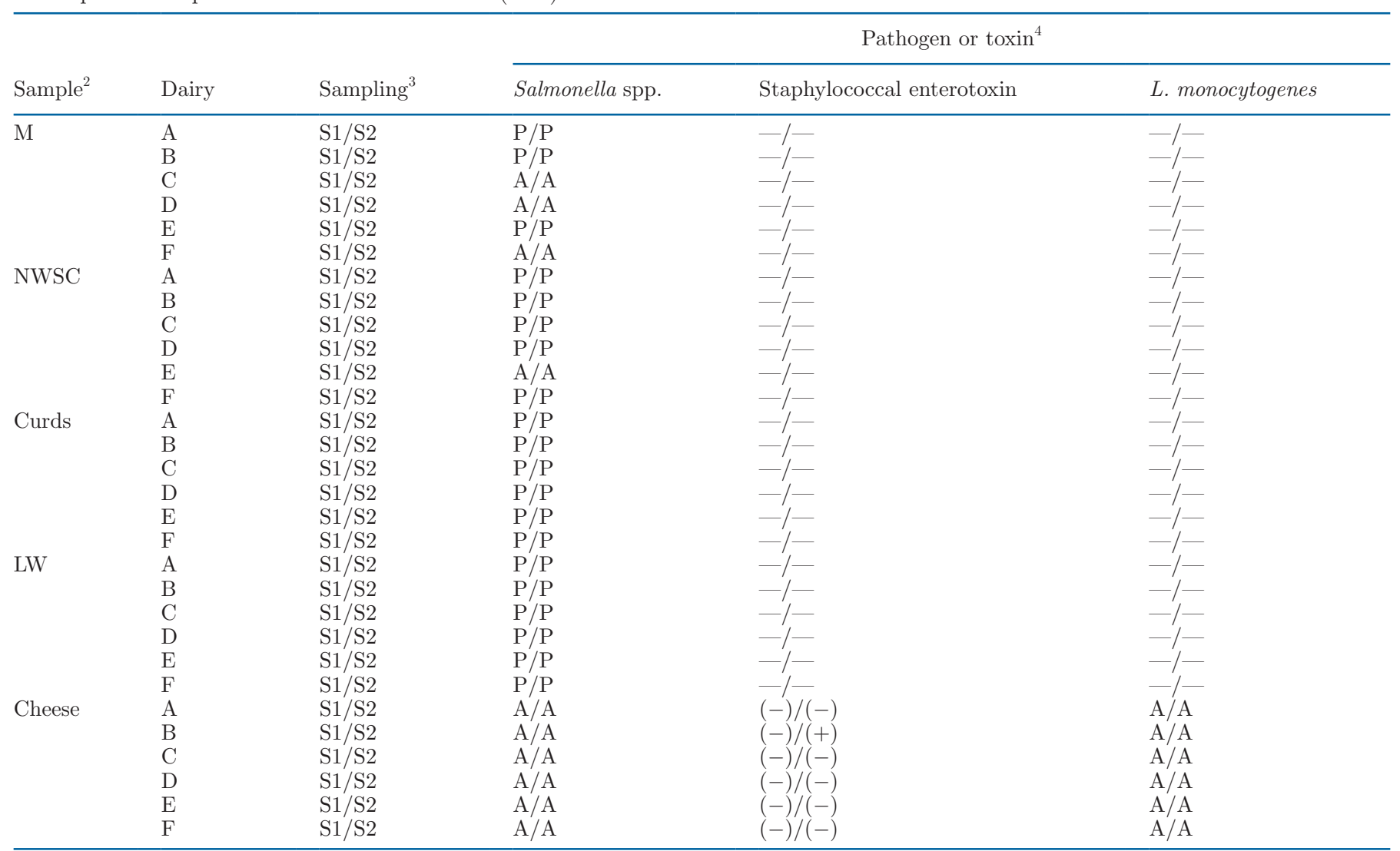

\footnotetext{
${ }^{1}$ Determinations were carried out in duplicate.
}

${ }^{2} \mathrm{M}=$ raw milk; NWSC $=$ natural whey starter culture; $\mathrm{LW}=$ leached whey.

${ }^{3} \mathrm{~S} 1=$ sampling $1 ; \mathrm{S} 2=$ sampling 2 .

${ }^{4} \mathrm{~A}=$ absent (not detected in $25 \mathrm{~g}$ of sample); $\mathrm{P}=$ present (detected in $25 \mathrm{~g}$ of sample). Negative $(-)$, positive $(+)$, not determined $(-)$.

milk be pasteurized and good manufacturing practices be implemented during the manufacture of cheese to ensure a safe product.

\section{CONCLUSIONS}

Poro de Tabasco cheese can be classified as a hard and full-fat fresh cheese based on its chemical composition. The use of raw whole cow's milk and an NWSC, in addition to a unique salting and pressing process and the application of a paraffin coating, define its typicity. However, the lack of standardized production processes among dairies results in cheeses of varying composition. Notably, the microbial populations decreased during the production process and E. coli, Salmonella spp., and $L$. monocytogenes were absent in the final cheeses for all dairies. Nevertheless, S. aureus and its toxins were found in some samples. Therefore, heat treatment for milk and good manufacturing practices should be implemented through the entire production process to ensure a safe product. Finally, the information described herein can support the collective trademark achieved by the cheese producers in Tabasco, Mexico, and could also be useful for obtaining a more extensive protection, such as a designation-of-origin status.

\section{ACKNOWLEDGMENTS}

The authors thank the Sectorial Research Fund for Agriculture, Livestock, Aquaculture, Agro-biotechnology, and Genetic Resources (SAGARPA-CONACyT, callfor-funding 2010-1, Mexico City, Mexico) for financing the following project: Improvement of the Productivity, Competitiveness, and Sustainability of the Milk Production Chain of Milk Livestock in Mexico, sub-project 5, Development Program for the Integration of Value along the Different Steps of the Production Chain: Strengthening Artisanal Cheesemaking through Technological Intervention to Assure the Quality, Safety, and Traceability of Mexican Cheeses. The authors also 
thank the National Council for Science and Technology (CONACyT) of Mexico for the graduate scholarship provided to author María de los Ángeles de la Rosa and Allison Marie Jermain (Ali Marie Translations) for editing and proofreading the manuscript. The authors hereby declare no conflicts of interest.

\section{REFERENCES}

Alegría, A., P. Álvarez-Martín, N. Sacristán, E. Fernández, S. Delgado, and B. Mayo. 2009. Diversity and evolution of the microbial populations during manufacture and ripening of Casín, a traditional Spanish, starter-free cheese made from cow's milk. Int. J. Food Microbiol. 136:44-51. https://doi.org/10.1016/j.ijfoodmicro 2009.09.023.

AOAC International. 2002. Official Methods of Analysis. AOAC International, Rockville, MD.

Banjara, N., M. J. Suhr, and H. E. Hallen-Adams. 2015. Diversity of yeast and mold species from a variety of cheese types. Curr. Microbiol. 70:792-800. https://doi.org/10.1007/s00284-015-0790-1.

Barbosa-Canovas, G. V., M. S. Tapia, and M. P. Cano. 2004. Novel Food Processing Technologies. 1st ed. CRC Press, Boca Raton, FL.

Beltrán-Barrientos, L. M., A. Hernández-Mendoza, A. F. GonzálezCórdova, H. Astiazarán-García, J. Esparza-Romero, and B. Vallejo-Córdoba. 2018. Mechanistic pathways underlying the antihypertensive effect of fermented milk with Lactococcus lactis NRRL B-50571 in spontaneously hypertensive rats. Nutrients 10(3):E262. https://doi.org/10.3390/nu10030262.

Borelli, B., E. Ferreira, I. Lacerda, G. Franco, and C. Rosa. 2006. Yeast populations associated with the artisanal cheese produced in the region of Serra da Canastra, Brazil. World J. Microbiol. Biotechnol. 22:1115-1119. https://doi.org/10.1007/s11274-006 $-9151-3$.

Cervantes-Escoto, F., A. Villegas de Gante, J. A. Cesín-Vargas, and A. Espinoza-Ortega. 2008. Los quesos mexicanos genuinos: Patrimonio cultural que debe rescatarse. 1st ed. Mundi Prensa, México.

Chombo-Morales, P., M. Kirchmayr, A. Gschaedler, E. Lugo-Cervantes, and S. Villanueva-Rodríguez. 2016. Effects of controlling ripening conditions on the dynamics of the native microbial population of Mexican artisanal Cotija cheese assessed by PCR-DGGE. Lebensm. Wiss. Technol. 65:1153-1161. https://doi.org/10.1016/j .lwt.2015.09.044.

Cocolin, L., D. Aggio, M. Manzano, C. Cantoni, and G. Comi. 2002. An application of PCR-DGGE analysis to profile the yeast populations in raw milk. Int. Dairy J. 12:407-411. https://doi.org/10 .1016/S0958-6946(02)00023-7.

Colak, H., H. Hampikyan, E. Bingol, and B. Ulusoy. 2007. Prevalence of L. monocytogenes and Salmonella spp. in Tulum cheese. Food Control 18:576-579. https://doi.org/10.1016/j.foodcont.2006.02 .004 .

Cretenet, M., S. Even, and Y. Le Loir. 2011. Unveiling Staphylococcus aureus enterotoxin production in dairy products: A review of recent advances to face new challenges. Dairy Sci. Technol. 91:127150. https://doi.org/10.1007/s13594-011-0014-9.

Cuevas-González, P. F., P. Y. Heredia-Castro, J. I. Méndez-Romero, A. Hernández-Mendoza, R. Reyes-Díaz, B. Vallejo-Cordoba, and A. F. González-Córdova. 2017. Artisanal Sonoran cheese (Cocido cheese): An exploration of its production process, chemical composition and microbiological quality. J. Sci. Food Agric. 97:44594466. https://doi.org/10.1002/jsfa.8309.

Dagdemir, E., and S. Ozdemir. 2008. Technological characterization of the natural lactic acid bacteria of artisanal Turkish White Pickled cheese. Int. J. Dairy Technol. 61:133-140. https://doi.org/10 $.1111 / j .1471-0307.2008 .00394 . x$.

Delbes-Paus, C., G. Dorchies, Z. Chaabna, C. Callon, and M. C. Montel. 2010. Contribution of hydrogen peroxide to the inhibition of Staphylococcus aureus by Lactococcus garvieae in interaction with raw milk microbial community. Food Microbiol. 27:924-932. https: //doi.org/10.1016/j.fm.2010.05.031.

El-Gazzar, F. E., and E. H. Marth. 1992. Salmonellae, salmonellosis, and dairy foods: A review. J. Dairy Sci. 75:2327-2343. https://doi .org/10.3168/jds.S0022-0302(92)77993-4.

EURL. 2014. Technical guidance document for conducting shelf-life studies on Listeria monocytogenes in ready-to-eat foods. European Union Reference Laboratory for Listeria monocytogenes 3: 1-47.

FAO. 1978. Codex general standard for cheese (CODEX STANDARD 283-1978). Food and Agriculture Organization. Accessed May 2018. http://www.fao.org/input/download/standards/175/CXS -283s.pdf.

Flores-Magallón, R., A. A. Oliva-Hernández, and J. A. Narváez-Zapata. 2011. Characterization of microbial traits involved with the elaboration of the Cotija cheese. Food Sci. Biotechnol. 20:9971003. https://doi.org/10.1007/s10068-011-0137-z.

Fox, P. F., and P. L. H. McSweeney. 1998. Dairy Chemistry and Biochemistry. 1st ed. Chapman and Hall, London, UK.

Fox, P. F., P. L. H. McSweeney, T. M. Cogan, and T. P. Guinee. 2004. Cheese: Chemistry, Physics and Microbiology. Vol. 1, 3rd ed. Elsevier Academic Press, San Diego, CA.

González-Córdova, A. F., C. Yescas, A. Ortiz-Estrada, M. A. De la Rosa-Alcaraz, A. Hernández-Mendoza, and B. Vallejo-Cordoba. 2016. Invited review: Artisanal Mexican cheeses. J. Dairy Sci 99:3250-3262. https://doi.org/10.3168/jds.2015-10103.

Gonzalez-Gonzalez, C. R., J. Machado, S. Correia, A. L. McCartney, J. Stephen Elmore, and P. Jauregi. 2019. Highly proteolytic bacteria from semi-ripened Chiapas cheese elicit angiotensin-I converting enzyme inhibition and antioxidant activity. Lebensm. Wiss. Technol. 111:449-456. https://doi.org/10.1016/j.lwt.2019.05.039.

Heredia-Castro, P. Y., J. I. Méndez-Romero, A. Hernández-Mendoza, E. Acedo-Félix, A. F. González-Córdova, and B. Vallejo-Cordoba. 2015. Antimicrobial activity and partial characterization of bacteriocin-like inhibitory substances produced by Lactobacillus spp. isolated from artisanal Mexican cheese. J. Dairy Sci. 98:8285-8293. https://doi.org/10.3168/jds.2015-10104.

Hintze, J. 2006. NCSS, PASS, and GESS. NCSS, Kaysville, UT.

ISO. 2002. ISO 6579:2002. Microbiology of food and animal feeding stuffs - Horizontal method for the detection of Salmonella spp. Accessed Dec. 27, 2019. https://www.iso.org/standard/29315.html

Marino, M., M. Maifreni, and G. Rondinini. 2003. Microbiological characterization of artisanal Montasio cheese: Analysis of its indigenous lactic acid bacteria. FEMS Microbiol. Lett. 229:133-140. https://doi.org/10.1016/S0378-1097(03)00816-4.

Melo, J., P. W. Andrew, and M. L. Faleiro. 2015. Listeria monocytogenes in cheese and the dairy environment remains a food safety challenge: The role of stress responses. Food Res. Int. 67:75-90. https://doi.org/10.1016/j.foodres.2014.10.031.

Morales, F., J. I. Morales, C. H. Hernández, and H. Hernández-Sánchez. 2011. Isolation and partial characterization of halotolerant lactic acid bacteria from two Mexican cheeses. Appl. Biochem. Biotechnol. 164:889-905. https://doi.org/10.1007/s12010-011 -9182-6.

Moreno-Enriquez, R. I., A. Garcia-Galaz, E. Acedo-Felix, H. Gonzalez-Rios, J. E. Call, J. B. Luchansky, and M. E. Diaz-Cinco. 2007. Prevalence, types, and geographical distribution of Listeria monocytogenes from a survey of retail queso fresco and associated cheese processing plants and dairy farms in Sonora, Mexico. J. Food Prot. 70:2596-2601. https://doi.org/10.4315/0362-028X-70.11.2596.

Park, J., and M. Kim. 2013. Comparison of dry medium culture plates for mesophilic aerobic bacteria in milk, ice cream, ham, and codfish fillet products. Prev. Nutr. Food Sci. 18:269-272. https://doi .org/10.3746/pnf.2013.18.4.269.

Renye, J. A., G. A. Somkuti, B. Vallejo-Cordoba, D. L. Van Hekken, and A. F. González-Córdova. 2008. Characterization of the microflora isolated from queso fresco made from raw and pasteurized milk. J. Food Saf. 28:59-75. https://doi.org/10.1111/j.1745-4565 .2007.00095.x.

Reyes-Díaz, A., V. Mata-Haro, J. Hernández, A. F. González-Cárdova, A. Hernández-Mendoza, R. Reyes-Díaz, M. J. Torres-Llanez, L. M. Beltrán-Barrientos, and B. Vallejo-Cordoba. 2018. Milk fermented 
by specific Lactobacillus strains regulates the serum levels of IL6, TNF-alpha and IL-10 cytokines in a LPS-stimulated murine model. Nutrients 10:691. https://doi.org/10.3390/nu10060691.

Schnürer, J., and J. Magnusson. 2005. Antifungal lactic acid bacteria as biopreservatives. Trends Food Sci. Technol. 16:70-78. https:// doi.org/10.1016/j.tifs.2004.02.014.

Sosa-Castañeda, J., A. Hernández-Mendoza, H. Astiazarán-García, H. S. Garcia, M. C. Estrada-Montoya, A. F. González-Córdova, and B. Vallejo-Cordoba. 2015. Screening of Lactobacillus strains for their ability to produce conjugated linoleic acid in milk and to adhere to the intestinal tract. J. Dairy Sci. 98:6651-6659. https:// doi.org/10.3168/jds.2014-8515.

SSA. 1994. NOM-091-SSA1-1994. Bienes y servicios. Leche pasteurizada de vaca. Disposiciones y especificaciones sanitarias. Secretaria de Salud. Diario Oficial de la Federación. Mexico. Accessed April 2018. http://www.salud.gob.mx/unidades/cdi/nom/091ssa14 .html.

SSA. 2010. NOM-243-SSA1-2010, Leche, fórmula láctea, producto lácteo combinado y derivados lácteos. Disposiciones y especificaciones sanitarias. Métodos de prueba. Secretaría de Salud. Diario Oficial de la Federación. Mexico. Accessed April 2018. http://dof.gob $. \mathrm{mx} /$ nota_detalle.php?codigo $=5160755$.
Torres-Llanez, M. J., B. Vallejo-Cordoba, M. E. Díaz-Cinco, M. A. Mazorra-Manzano, and A. F. González-Córdova. 2006. Characterization of the natural microflora of artisanal Mexican Fresco cheese. Food Control 17:683-690. https://doi.org/10.1016/j .foodcont.2005.04.004.

Torres-Vitela, M. R., M. Mendoza-Bernardo, J. Castro-Rosas, C. A. Gomez-Aldapa, L. E. Garay-Martinez, V. Navarro-Hidalgo, and A. Villarruel-López. 2012. Incidence of Salmonella, Listeria monocytogenes, Escherichia coli O157: H7, and staphylococcal enterotoxin in two types of Mexican fresh cheeses. J. Food Prot. 75:79-84. https://doi.org/10.4315/0362-028X.JFP-11-258.

Villegas, A., F. Cervantes, A. Cesín, O. Espinoza, A. Hernández, A. Santos, and A. R. Martínez. 2014. Atlas de los quesos mexicanos genuinos. 1st ed. BBA (Biblioteca, Básica de Agricultura), México.

\section{ORCIDS}

Adrián Hernández-Mendoza @ https://orcid.org/0000-0002-2360-7484 Belinda Vallejo-Cordoba @ https://orcid.org/0000-0001-8312-7039

Aarón F. González-Córdova @ https://orcid.org/0000-0002-0674-4217 